\title{
Effects of prey concentration on ingestion rates of European sardine Sardina pilchardus larvae in the laboratory
}

\author{
C. Caldeira ${ }^{1}$, A. M. P. Santos ${ }^{2}$, P. Ré ${ }^{1}$, M. A. Peck ${ }^{3}$, E. Saiz ${ }^{4}$, S. Garrido ${ }^{1, *}$ \\ ${ }^{1}$ Centro de Oceanografia, Laboratório Marítimo da Guia, Faculdade de Ciências, Universidade de Lisboa, \\ Avenida Nossa Senhora do Cabo, No. 939, 2750-374 Cascais, Portugal \\ ${ }^{2}$ Portuguese Institute of the Ocean and the Atmosphere (IPMA), 1449-006 Lisbon, Portugal \\ ${ }^{3}$ Institute for Hydrobiology and Fisheries Science, University of Hamburg, Olbersweg 24, 22767 Hamburg, Germany \\ ${ }^{4}$ Institut de Ciències del Mar - CSIC, Ps. Marítim de la Barceloneta 37-49, 08003 Barcelona, Spain
}

\begin{abstract}
The quantification of prey requirements for larval fish is essential to understand how environmental factors act to restrict suitable habitats and recruitment success in marine fish. The effect of prey concentration on ingestion rates of the European sardine Sardina pilchardus was estimated for larvae through $50 \mathrm{~d}$ post-hatch $(\mathrm{dph})$ under controlled laboratory conditions at $15^{\circ} \mathrm{C}$. Prey were nauplii and copepodites of the calanoid copepod Acartia grani, which were provided to larvae at 3 concentrations $\left(0.5,2\right.$ and 6 nauplii ml ${ }^{-1}$ and $0.1,0.5$ and 1 copepodites $\mathrm{ml}^{-1}$ ). Larvae were not able to capture copepod nauplii at the beginning of exogenous feeding, suggesting that early larvae depend on smaller prey types and/or less mobile prey than copepods. The mean size of prey found in the guts of sardine larvae increased from 145 to $348 \mu \mathrm{m}$ for larvae of total length increasing from 6 to $18 \mathrm{~mm}$, respectively. Maximum ingestion rates $\left(232 \pm 8.0 \mu \mathrm{g} \mathrm{Clarva}^{-1} \mathrm{~h}^{-1}\right)$ were reached at the highest prey concentration diet for individuals $>40 \mathrm{dph}$ (1500 to $2500 \mu \mathrm{g} \mathrm{C}$ dry weight). These feeding rates are higher than values previously reported for the larvae of small pelagic fish. The inability of sardine larvae to feed at low prey concentrations, particularly during the first weeks of life, suggests that this species relies on and is adapted to forage within dense prey patches. Given this feeding strategy, bottom-up processes causing food limitation may strongly impact the survival and growth of sardine larvae.
\end{abstract}

KEY WORDS: Sardina pilchardus · Ingestion rate · Gut content - Acartia grani · Prey selectivity · Prey size $\cdot$ Fish larvae $\cdot$ Small pelagic fish

Resale or republication not permitted without written consent of the publisher

\section{INTRODUCTION}

Within the several theories proposing explanations for the recruitment variability of fish populations (e.g. Hjort 1914, Lasker 1975, Bakun 1996), processes acting on early life stages are considered to be the most important for establishing year-class success in many marine fish stocks (Houde \& Schekter 1980). Ascertaining the main causes of mortality during the larval period is essential to improve our understanding and prediction capability of recruitment success of marine fishes.

Predation, ocean circulation patterns and food limitation are considered to be the most important factors influencing larval survival (Anderson 1988, Peck \& Hufnagl 2012). Feeding can affect larval mortality directly through starvation or indirectly by reducing growth rates, causing larvae to spend more time in early life stages particularly vulnerable to predation mortality (Houde \& Schekter 1980, Munk \& Kiørboe 
1985, Anderson 1988, Munk 1997). Survival of fish larvae depends, consequently, on their ability to find, capture and ingest sufficient quantities of appropriate prey to avoid starvation and to ensure high rates of growth (Blaxter 1963, Checkley 1982, Pryor \& Epifano 1993). In this regard, it is crucial to know the changes in the suitable prey field (species, sizes) and the required prey concentrations to support survival and high rates of feeding and growth through fish larvae ontogeny.

The European sardine Sardina pilchardus is distributed along the eastern North Atlantic coast, from Iceland and the North Sea to Senegal and the Mediterranean Sea (Whitehead et al. 1988). One of the main areas of sardine spawning in the northeast Atlantic is the Iberian Peninsula (Stratoudakis et al. 2007), where sardine larvae often dominate the ichthyoplankton community (Garrido et al. 2009). Although the abundance and recruitment success of sardine fluctuate widely from year to year, in recent years the size of the population in Iberian waters has declined (ICES 2013).

Recent field studies suggest that, at least during particular phases of larval development, sardine larvae are almost exclusively zooplanktivorous and calanoid copepods seem to be preferentially selected (Conway et al. 1994, Fernández \& González-Quirós 2006, Voss et al. 2009, Catalán et al. 2010, Morote et al. 2010). Sardine larvae are likely able to ingest phytoplankton but early larvae have a poorly developed digestive system and are probably unable to digest non-naked microalgae cells (Blaxter 1969). Unfortunately, feeding rates of sardine larvae, and those of other small pelagic fish larvae, cannot be properly estimated by analysing gut contents of larvae collected in the sea due to, among other factors, a very high percentage of empty guts (e.g. $90 \%$ in Blaxter (1969), 68\% in Voss et al. (2009), 70\% in Morote et al. (2010)). Clupeoid larvae have straight alimentary tracts and rapid rates of food passage, thus, empty guts are probably caused by defecation or regurgitation (Fernández \& González-Quirós 2006, Morote et al. 2010, Borme et al. 2013). Therefore, it is necessary to perform complementary laboratory studies to quantify rates of larval feeding, and identify prey types and concentrations providing adequate energy to support larval survival.

Laboratory research on early life stages of small pelagic fish has shown that larvae require high concentrations of different prey types to achieve growth rates similar to those in nature (Hunter \& Thomas 1974, Theilacker 1987, Garrido et al. 2012, Peck et al. 2013). Moreover, larvae either grow slowly or often die when provided only monospecific diets (e.g. dinoflagellates or copepod nauplii), likely reflecting the rapidly changing optimal prey sizes and/or types required as larvae grow and develop (Lasker et al. 1970, Hunter 1976, Garrido et al. 2012). Natural conditions at which larvae are able to survive and grow can be inferred from laboratory-derived feeding rates in relation to prey availability. Furthermore, laboratory data on aspects of larval feeding (e.g. ingestion rates and prey-size ranges in relation to larval size and prey concentration) are needed to parameterize foraging sub-routines of individual-based models (Peck \& Hufnagl 2012), tools which may yield fundamental insights into the mechanisms of environmental regulation of recruitment, aiding advice needed to establish sustainable exploitation rates of fish populations (Peck et al. 2013).

The present work provides the first laboratory study on the feeding behaviour of the larvae of European sardine. We determined the ingestion rates of the larvae in relation to larvae age and to prey size and concentration. Our study encompassed larvae between 5 and $50 \mathrm{~d}$ post-hatch $(\mathrm{dph})$ that were fed nauplii and copepodites of the calanoid copepod Acartia grani. This and other calanoid species account for the main prey of sardine larvae in situ. Our estimates of foraging capacity are discussed in relation to field growth patterns and recent estimates of metabolic losses.

\section{MATERIALS AND METHODS}

\section{Larval rearing}

The sardine larvae used in the experiments were hatched from eggs spawned by captive sardines Sardina pilchardus, captured by purse-seine fishery in the fishing port of Peniche (Western Portugal) during 2009 and 2010 and maintained in a large cylindrical tank (15000 l) in the Oceanário de Lisboa. Adult fish started spawning naturally by adjusting the photoperiod and temperature to natural conditions. The eggs were collected from the broodstock using $500 \mu \mathrm{m}$ mesh egg collector bags placed in the skimmers of the tank. Eggs were counted and transferred to $30 \mathrm{l}$ cylindrical tanks (stocking tanks), where they were incubated at $15^{\circ} \mathrm{C}$ and a salinity of 35.0 . This temperature corresponds to the peak of the spawning season of sardines off Portugal (Stratoudakis et al. 2007). The light regime was $16 \mathrm{~h}$ light: $8 \mathrm{~h}$ dark and gentle aeration was used to maintain steady water circulation and high oxygen concentrations. 
Sardine larvae were reared in the stocking tanks until $50 \mathrm{dph}$. The diet of sardine larvae in the stocking tanks comprised the dinoflagellate Gymnodinium sp., the rotifer Brachionus sp., and nauplii, copepodites and adults of the copepod Acartia grani (Table 1); these prey proved suitable to provide high rates of growth and survival in sardine larvae in previous experiments (S. Garrido et al. unpubl. data). The concentration of prey remaining in the larval tanks was monitored daily and new prey added to maintain constant values throughout the experimental period. The microalgae Nannochloropsis sp. was added daily to the stocking tanks (green-water method). Stock cultures of live prey for sardines (A. grani and rotifers Brachionus sp.) were fed ad libitum with Rhodomonas sp. and Nannochloropsis sp., respectively.

\section{Larval feeding experiments}

Feeding experiments consisted of determining the ingestion rates of sardine larvae fed different diets. Larvae were fed every $5 \mathrm{~d}$ between 5 and $50 \mathrm{dph}$. The 3 diets consisted of increasing concentrations of different developmental stages of the calanoid copepod A. grani (Table 2).

Every 5 d, 3 to 7 larvae were randomly selected and placed into each of 9 experimental $5 \mathrm{l}$ glass beakers (with $4 \mathrm{l}$ sea water) and acclimated for $18 \mathrm{~h}$ without prey. The experimental beakers remained static, with no air supplementation and were kept at the same temperature $\left(15^{\circ} \mathrm{C}\right)$ and salinity (35) as the stocking tanks. To maintain the temperature conditions, stocking tanks and experimental beakers were placed in temperature-controlled water baths. At the start of measurements, beakers were randomly selected to receive 1 of the 3 food concentrations. Food items were added and larvae were allowed to feed for $4 \pm 0.17 \mathrm{~h}$, after which the water in the beakers was rapidly cooled to $4-6^{\circ} \mathrm{C}$, to minimize any further

Table 1. Prey offered to sardine larvae reared in the stocking tanks as a function of age (days post-hatch, dph)

\begin{tabular}{|c|c|c|c|}
\hline & Gymnodinium sp. & Brachionus sp. & Acartia grani \\
\hline $0 \mathrm{dph}$ & 1500 cells ml $^{-1}$ & & \\
\hline $3 \mathrm{dph}$ & & 25 rotifers $\mathrm{ml}^{-1}$ & \\
\hline 4 dph onwards & & & 5 nauplii $\mathrm{ml}^{-1}$ \\
\hline 20 dph onwards & & & $\begin{array}{c}5 \text { nauplii } \mathrm{ml}^{-1} \\
2 \text { copepodites } \mathrm{ml}^{-1}\end{array}$ \\
\hline 30 dph onwards & & & $\begin{array}{c}2 \text { nauplii } \mathrm{ml}^{-1} \\
2 \text { copepodites ml} \mathrm{m}^{-1} \\
2 \text { adults } \mathrm{ml}^{-1}\end{array}$ \\
\hline
\end{tabular}

Table 2. Feeding regimes used in the sardine larvae ingestion experiments. The prey were nauplii and copepodites of the calanoid copepod Acartia grani

\begin{tabular}{|ll|}
\hline Concentration & Feeding regimes \\
\hline Low & 0.5 nauplii ml $\mathrm{ml}^{-1}+0.1$ copepodite $\mathrm{ml}^{-1}$ \\
Intermediate & 2 nauplii $\mathrm{ml}^{-1}+0.5$ copepodite $\mathrm{ml}^{-1}$ \\
High & 6 nauplii $\mathrm{ml}^{-1}+1$ copepodite $\mathrm{ml}^{-1}$ \\
\hline
\end{tabular}

digestion and/or feeding. At each food concentration, 2 control beakers were used (food but no larvae) (thus, a total of 15 beakers used). All larvae were then rapidly removed and anesthetized with MS-222, their total length (TL) was measured in vivo under a stereoscopic microscope $( \pm 0.05 \mathrm{~mm}$, micrometer on a Zeiss Stemi 2000 dissecting scope), and larvae were stored in formaldehyde until further processing. The water of each experimental and control beaker was sieved $(55 \mu \mathrm{m})$ and stored with $2 \%$ Lugol solution and initial (control beakers) and final (larval beakers) prey concentrations were determined later. Larval mortality was inspected and registered for all experimental beakers at the end of the conditioning (starvation) period, immediately before food was added and the $4 \mathrm{~h}$ experimental feeding period begun. Dead larvae were not considered in any further calculations or analyses.

\section{Larval growth}

The TL of larvae used in the feeding experiments was determined on each experimental day. Additionally, 3 to 10 larvae were collected from the stock tank on each measurement day, their TL was measured, and larvae were frozen at $-80^{\circ} \mathrm{C}$ for subsequent dry weight (DW) determination. Larvae DW was obtained $( \pm 0.1 \mu \mathrm{g}$, Sartorius microbalance, XM1000P) after freeze drying (Thermo PL9000/HSC, 36 h). To estimate sardine growth rate during the experimental period from hatching to $50 \mathrm{dph}$, larval length data and age data were fitted to a Laird-Gompertz growth curve by an iterative nonlinear regression routine:

$$
\mathrm{TL}=L_{0} \mathrm{e}^{\left(\frac{A_{0}}{\lambda}\right)\left(1-\mathrm{e}^{-\lambda t}\right)}
$$

where TL is total length in $\mathrm{mm}, L_{0}$ is initial length at time $0, A_{0}$ is the growth rate at time $0, \lambda$ is the rate of exponential decay and $t$ is age in days. 
The increase of larval dry weight (DW) per age was also fitted to a Laird-Gompertz weight curve by an iterative nonlinear regression routine:

$$
\operatorname{LogDW}=W_{0} \mathrm{e}^{\left(\frac{A_{0}}{\lambda}\right)\left(1-\mathrm{e}^{-\lambda t}\right)}
$$

where DW is larval dry weight in $\mu g, W_{0}$ is the dry weight at hatching in $\mu \mathrm{g}, A_{0}$ is the dry weight at time 0 .

\section{Feeding rates}

Ingestion rates over the $4 \mathrm{~h}$ feeding period were determined by comparing the initial and final prey concentrations in the control and larval beakers. Prey (copepod A. grani) concentration was quantified in 4 subsamples using a plankton counting chamber (accounting for 10 to $20 \%$ of the sample), under a stereoscope microscope (Olympus SZ-PT). Subsequently, 40 to 50 prey items (nauplii and copepodites) of each experiment were digitally photographed at 40× magnification (Canon EOS 1100D), and measured using the Image-Pro Plus image analysis software version 4.5.0.29.

For each replicate larval beaker, ingestion $\left(I_{i}\right.$ prey larvae $\left.{ }^{-1} \mathrm{~h}^{-1}\right)$ and clearance $\left(F_{;} \mathrm{ml}\right.$ larvae $\left.{ }^{-1} \mathrm{~h}^{-1}\right)$ rates were calculated using the following formulas:

$$
I=\left(\frac{C_{\mathrm{i}}-C_{1}-\left(C_{\mathrm{i}}-C_{\mathrm{f}}\right)}{n}\right) / t
$$

and

$$
F=\left(V \times\left(\frac{\ln \left(C_{\mathrm{f}} / C_{\mathrm{i}}\right)-\ln \left(C_{\mathrm{l}} / C_{\mathrm{i}}\right)}{t}\right)\right) / n
$$

where $C_{\mathrm{i}}$ is the initial prey concentration, $C_{\mathrm{f}}$ is the average final prey concentration in the control beakers, $C_{1}$ is the final prey concentration in the larval beakers, $n$ is the number of larvae that remained alive in the experiment, $t$ is the duration of the experiment in hours and $V$ is the volume of water in the experimental beaker. Prior to calculations, we compared the decrease of prey concentration between control beakers (with only prey) and larvae beakers (with prey and larvae) using $t$ tests. Experimental beakers were used in further analyses only when concentrations in the 3 replicate beakers with larvae were significantly lower than those computed for the control beakers (i.e. feeding took place).

Prey items were identified to stage at the beginning and end of the experimental period.
To evaluate changes in selectivity patterns through larval ontogeny, we calculated the Chesson $\alpha$ statistic (Chesson 1983):

$$
\alpha_{j}=\frac{\frac{r_{j}}{p_{j}}}{\sum_{j=1}^{m} \frac{r_{j}}{p_{j}}}
$$

where $m$ is the number of prey types (either nauplii or copepodite), $r_{j}$ is the proportion of prey type $j$ ingested and $p_{j}$ is the proportion of prey type $j$ in the experimental beakers. Selection was interpreted as neutral if the $\mathrm{m}^{-1}$ value fell within the $95 \%$ confidence interval for $\alpha_{j}$ at a particular larval age, and as positive or negative if the $95 \%$ confidence interval was higher or lower than $\mathrm{m}^{-1}$, respectively.

\section{Gut contents}

The gut content of each larva was analysed. The entire gut from each larva was excised and dissected using a fine needle, placed in a drop of glycerine on a glass slide and examined under a stereoscope microscope. Prey organisms were identified, counted and digitally photographed at $6.3 \times$ magnification (Canon EOS 1100D). Subsequently, prey lengths were measured using the Image-Pro Plus image analysis software version 4 5.0.29 and the carbon contents of prey were estimated using the equation of van der Lingen (2002). Feeding incidence was calculated as the percentage of larvae examined containing at least one prey in the gut.

\section{Data analysis}

Analysis of covariance (ANCOVA) was used to assess whether the regressions relating sardine larvae ingestion rates (or clearance rates) and larval age were comparable among the 3 prey concentrations. Specifically, we tested for differences in ingestion rate ( $\mu \mathrm{g} \mathrm{C}$ larvae $\mathrm{e}^{-1} \mathrm{~h}^{-1}$ ) or clearance rate $\left(\mathrm{ml}\right.$ larvae $^{-1}$ $\mathrm{h}^{-1}$ ) depending on larval age (continuous variable) and diet type (factorial variable design with 3 factors corresponding to the concentrations of the 3 diets). To test the relationship between larval length and prey size, a regression model was used on nontransformed variables.

All graphics and statistical analyses were performed using the open source software $\mathrm{R}$ version 2.9.2 (R Development Core Team). 


\section{RESULTS}

\section{Larval growth}

Sardine larvae hatched $48 \mathrm{~h}$ after the eggs were collected from the adult spawning tank, and had a yolk sac, non-pigmented eyes and a closed mouth. Larval TL at-hatch was between 3.1 and $4.5 \mathrm{~mm}$ (mean \pm SE: $3.8 \pm 0.34 \mathrm{~mm}$ ). At $4 \mathrm{dph}$, the yolk sac was totally absorbed and larvae started exogenous feeding. At $5 \mathrm{dph}$, sardine larvae had pigmented eyes, and pectoral fins started to develop, while the caudal fin started to form at $25 \mathrm{dph}$. At $50 \mathrm{dph}$ larval TL had increased up to $18.7 \pm 1.64 \mathrm{~mm}$ (Fig. 1). The relationship between TL and age was statistically significant and described well by the Laird-Gompertz curve:

$$
\mathrm{TL}=3.859 \mathrm{e}^{\left(\frac{0.069}{0.088}\right)\left(1-\mathrm{e}^{-0.088 t}\right)}
$$

$(\mathrm{p}<0.001, \mathrm{n}=408)$. Sardine larvae weight increased throughout the ontogeny from $0.03 \pm 0.006 \mu \mathrm{g}$ at
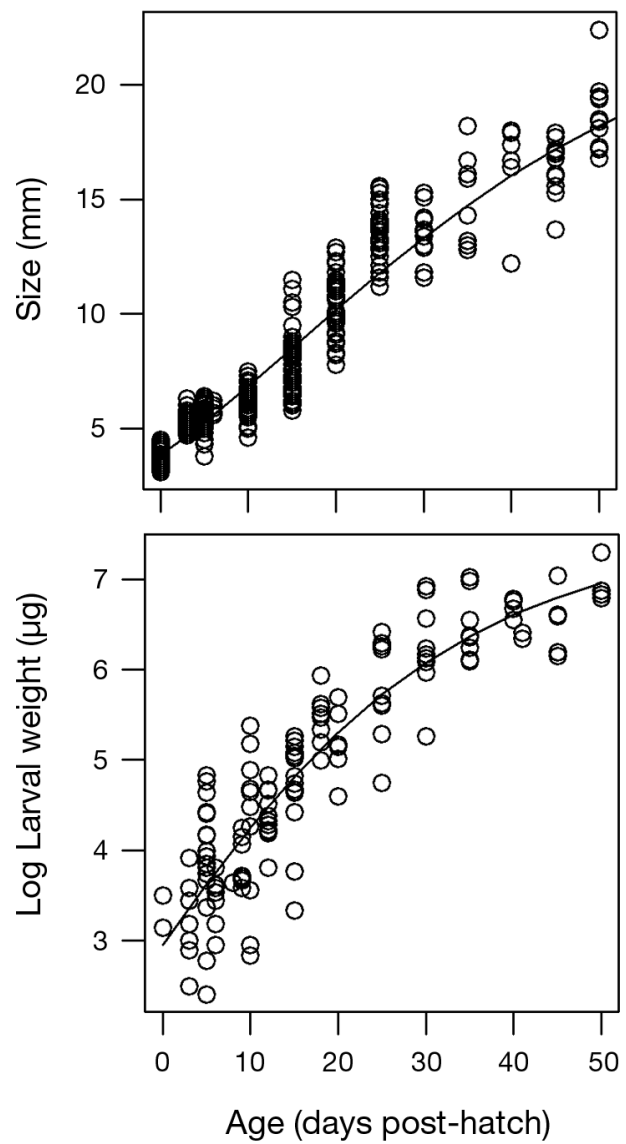

Fig. 1. Change in size and dry weight of sardine larvae reared in the stocking tank at optimum feeding levels. Size and dry weight were fitted to Laird-Gompertz curves. Parameters of the equations are given in the text hatching to $1.44 \pm 0.873 \mu \mathrm{g}$ at $50 \mathrm{dph}$ (Fig. 1). The relationship between larval DW and age was described by:

$$
\log \mathrm{DW}=2.95 \mathrm{e}^{\left(\frac{0.046}{0.049}\right)\left(1-\mathrm{e}^{-0.049 t}\right)}
$$

$(\mathrm{p}<0.001, \mathrm{n}=151)$.

\section{Feeding rates}

The decrease in prey concentration during the feeding incubations was from 5 to $41 \%$ (mean \pm SE: $15.3 \pm 10.1 \%)$ for nauplii, and 3.2 to $76.3 \%(28.7 \pm$ $19.2 \%)$ for copepodites. Ingestion rates of sardine larvae increased significantly with larval age $(F$-test $=$ $85.9, \mathrm{p}<0.001)$ and prey concentration $(F$-test $=50.1$, $\mathrm{p}<0.001)$ as shown by the ANCOVA model $\left(\mathrm{r}^{2}=0.81\right.$, $\mathrm{n}=73$ ). Sardine larvae aged between 5 and $10 \mathrm{dph}$ (5.3 and $6.9 \mathrm{~mm} \mathrm{TL}$, respectively) were not able to feed or had very low ingestion rates at each of the 3 prey concentrations (Fig. 2). Ingestion rates markedly increased after $>45 \mathrm{dph}$ or $>15.9 \mathrm{~mm}$ TL at the low prey concentrations (maximum ingestion rates reached $46 \pm 35.1$ nauplii larvae ${ }^{-1} \mathrm{~h}^{-1}$ and $18 \pm$ 0.5 copepodites larvae ${ }^{-1} \mathrm{~h}^{-1}$ at $50 \mathrm{dph}$ for an $18.1 \mathrm{~mm}$ larva). At the intermediate concentration, ingestion rates increased at $20 \mathrm{dph}$ and $10.1 \mathrm{~mm}$ and reached $44 \pm 61.9$ nauplii larvae ${ }^{-1} \mathrm{~h}^{-1}$ and $75 \pm 38.0$ copepodites larvae ${ }^{-1} \mathrm{~h}^{-1}$ at $50 \mathrm{dph}$ with $18.1 \mathrm{~mm}$ TL. At the high prey concentration, ingestion rates increased at 20 dph with $10.1 \mathrm{~mm}$ TL and reached $863 \pm$ 40.0 nauplii larvae ${ }^{-1} \mathrm{~h}^{-1}$ and $285 \pm 8$ copepodites larvae $\mathrm{e}^{-1} \mathrm{~h}^{-1}$ at $50 \mathrm{dph}$ with $18.1 \mathrm{~mm}$ TL.

Clearance rates of sardine larvae increased significantly with larval age (ANCOVA regression $\left(\mathrm{r}^{2}=\right.$ $0.29, \mathrm{n}=73, \mathrm{p}<0.001$ ) but were not different among the 3 prey concentrations. The largest ontogenetic changes in clearance rates occurred when larvae were $>25 \mathrm{dph}(>11.8 \mathrm{~mm} \mathrm{TL})$. Clearance rates were higher on copepodites $\left(145 \pm 138.3 \mathrm{ml} \mathrm{larvae}^{-1} \mathrm{~h}^{-1}\right)$ than on nauplii $\left(31 \pm 33.6 \mathrm{ml}\right.$ larvae $\left.\mathrm{e}^{-1} \mathrm{~h}^{-1}\right)$ of $A$. grani (Fig. 2). Except for early larvae, feeding rates increased linearly with food concentration without reaching a saturation point (Fig. 3).

Total carbon intake increased with larval body mass (i.e. size and age) and prey concentration (Fig. 4). Larvae $\geq 40 \mathrm{dph}$ ( $\geq 15.9 \mathrm{~mm} \mathrm{TL}$ and ranging from 1500 to $2500 \mu \mathrm{g}$ DW) consumed $13 \pm 3.4 \mathrm{SD}, 44$ \pm 26.2 and $231 \pm 8.0 \mu \mathrm{g} \mathrm{C}$ larvae ${ }^{-1} \mathrm{~h}^{-1}$ when feeding at the low, intermediate and high prey concentrations, respectively (Fig. 4). In terms of weight-specific rates, mean values were $1.5 \pm 1.70 \% \mathrm{BC}$ (body carbon $\mathrm{h}^{-1}$ ) for low concentration, $14.3 \pm 28.94 \% \mathrm{BC}$ for 

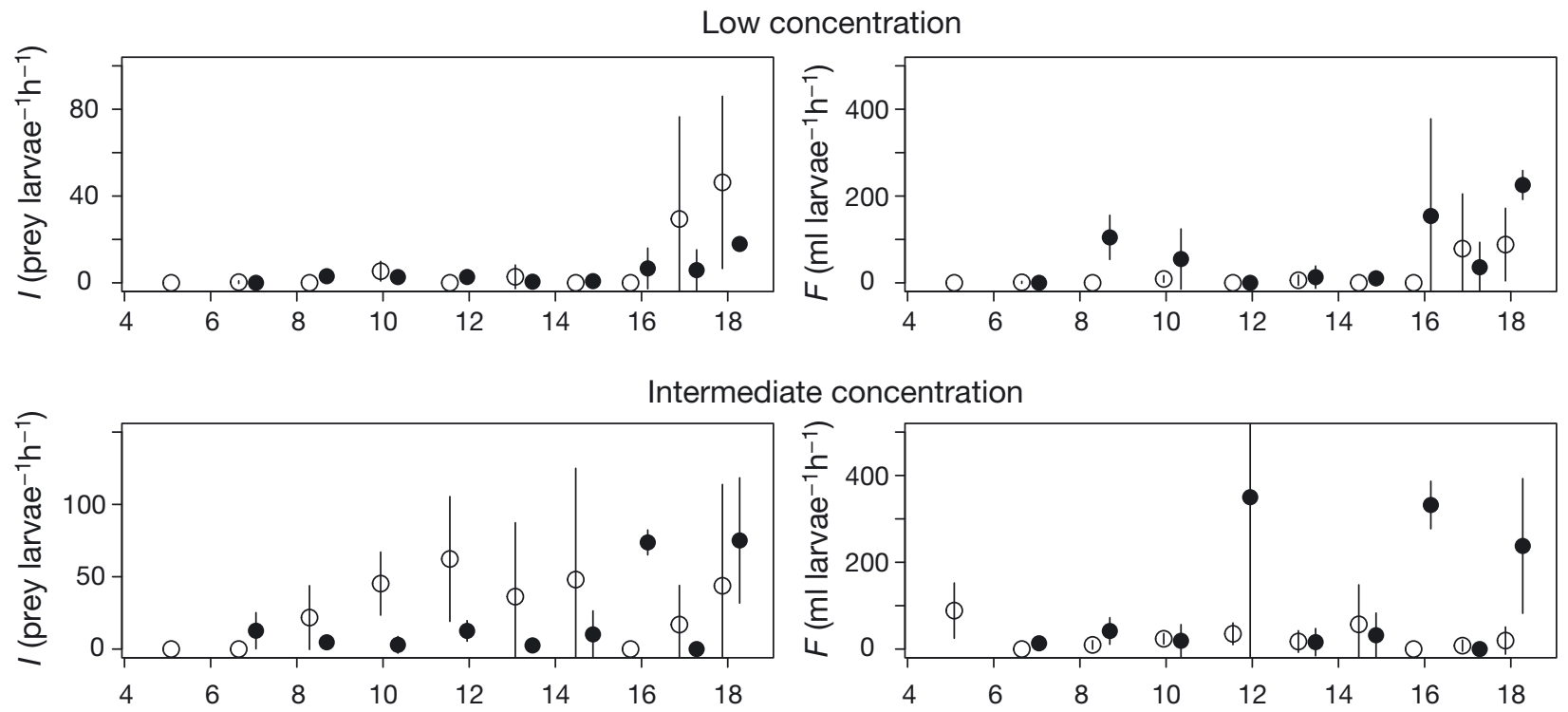

High concentration
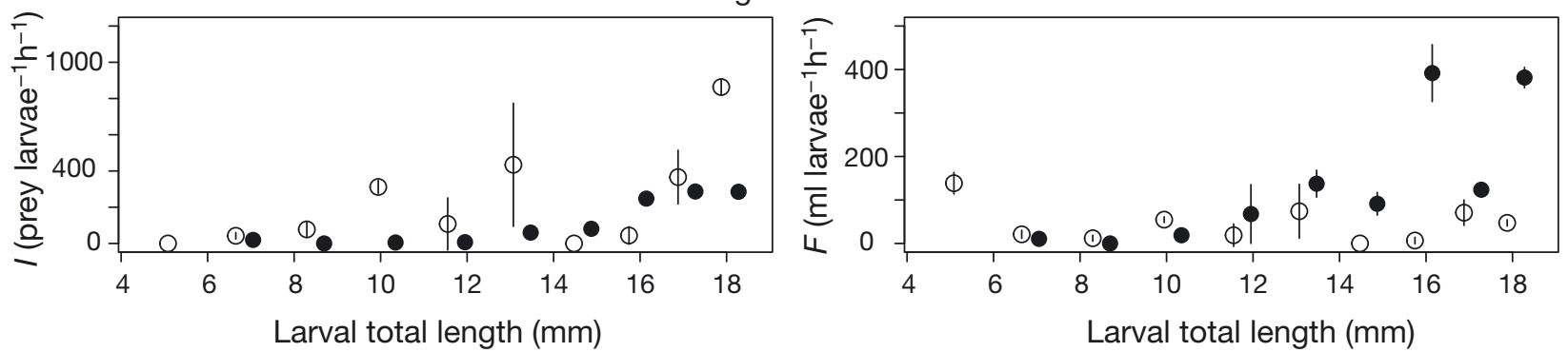

Fig. 2. Ingestion ( $I$, prey larvae $\mathrm{e}^{-1} \mathrm{~h}^{-1}$; left panels), and clearance $\left(F, \mathrm{ml}\right.$ larvae $\mathrm{e}^{-1} \mathrm{~h}^{-1}$; right panels) rates of sardine larvae during the ingestion experiment, offered different concentrations of nauplii (O) and copepodites ( $)$ of the calanoid copepod Acartia grani. Diet concentrations are described in Table 2. Values are expressed as means and vertical lines are $95 \%$ confidence intervals. Note that the $y$-axes scales are different between the diets
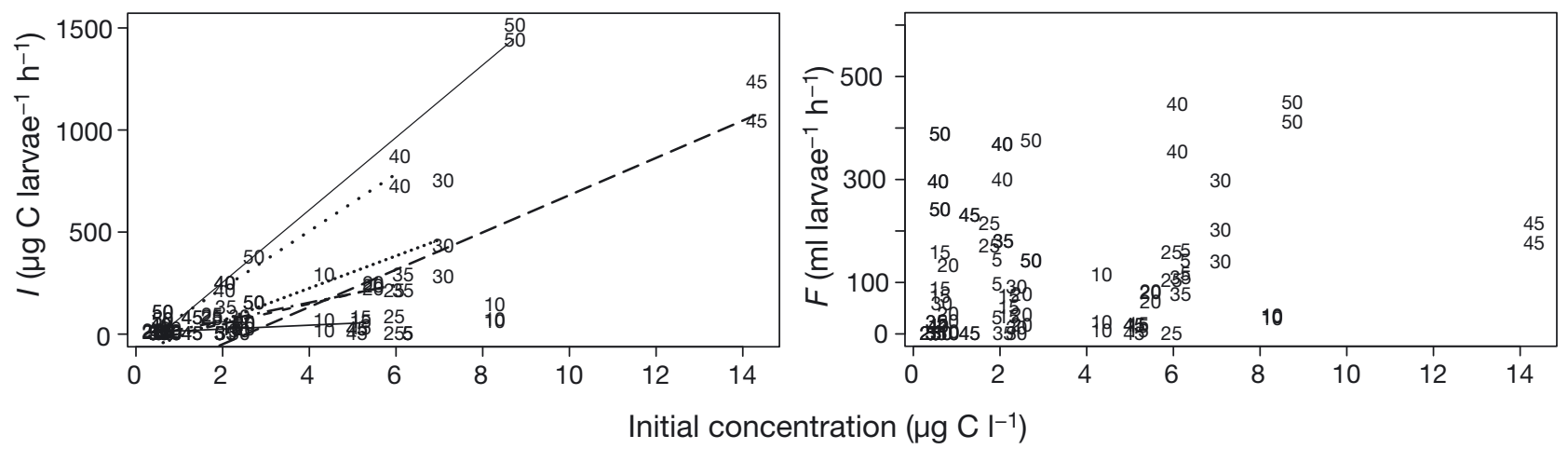

Fig. 3. Relationship between ingestion $\left(I, \mu \mathrm{g} C\right.$ larvae $\left.\mathrm{e}^{-1} \mathrm{~h}^{-1}\right)$ and clearance $\left(F, \mathrm{ml}\right.$ larvae $\left.\mathrm{e}^{-1} \mathrm{~h}^{-1}\right)$ rates of sardine larvae and initial

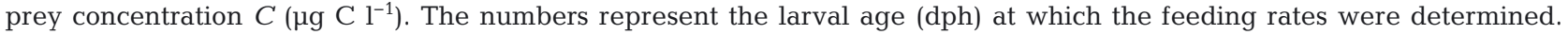
Linear regressions of ingestion $(I)$ as a function of the initial prey concentration $(C)$ : $I_{15 \mathrm{dph}}=5.8 \times 9.4 C, I_{20 \mathrm{dph}}=-47.3 \times 48.9 C$, $I_{30 \mathrm{dph}}=-91.3 \times 79.1 C, I_{35 \mathrm{dph}}=-22.2 \times 44.1 C, I_{40 \mathrm{dph}}=-55.4 \times 140.0 C, I_{45 \mathrm{dph}}=-232.1 \times 91.2 C, I_{50 \mathrm{dph}}=-101.2 \times 177.4 C$ 

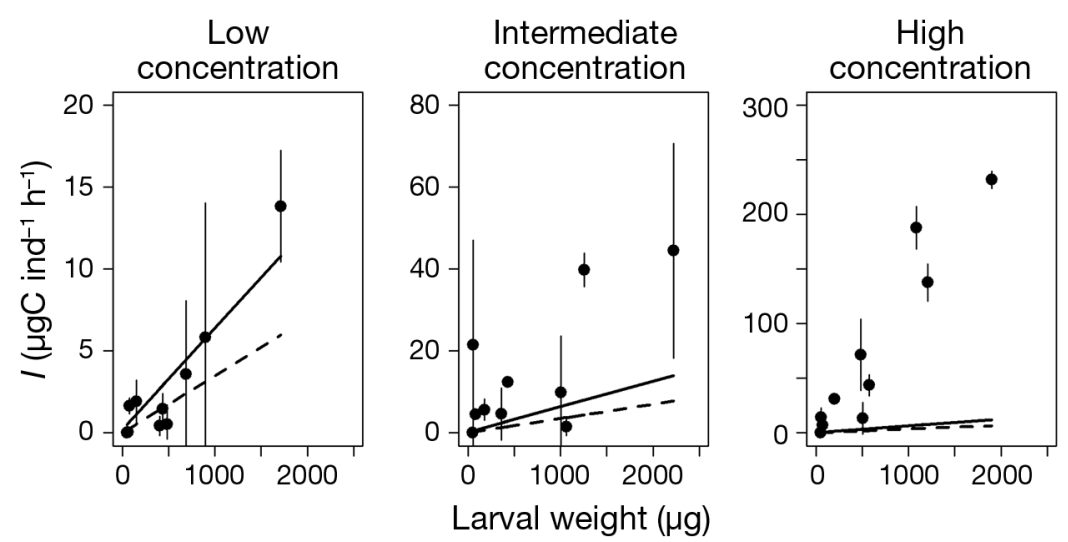

Fig. 4. Total carbon biomass ( $\mu \mathrm{g} \mathrm{C}$ ind $^{-1} \mathrm{~h}^{-1}$ ) ingested by sardine larvae from 49.1 to $2221.2 \mu \mathrm{g}$ DW (5 to $50 \mathrm{dph}$ ), fed 3 different concentrations of the calanoid copepod Acartia grani (nauplii and copepodites). Diet concentrations are described in Table 2. Calculation of food intake necessary to achieve larval growth rates of wild sardine $(y=0.199+0.006 x$; solid line $)$ and food necessary to achieve the respiration rates $(y=0.056 x$; dashed line) estimated in Moyano et al. (2014). Values are expressed as mean \pm SD. Note the $y$-axes scales are different between the diets

intermediate concentration, and $29.6 \pm 19.02 \% \mathrm{BC}$ for high concentration diets.

Prey size increased with larval age (Fig. 2). For the 3 prey concentrations, early sardine larvae measuring $<14.7 \mathrm{~mm} \quad$ TL $(<35 \mathrm{dph})$ preferentially ingested nauplii. The intake of copepodites increased with age and size and, in some cases, more copepodites were ingested compared with nauplii. At the intermediate prey concentration, $40 \mathrm{dph}$ larvae (15.9 mm TL) ingested only copepodites at a mean \pm SE rate of $74 \pm 7.6$ prey larva ${ }^{-1} \mathrm{~h}^{-1}(227 \pm$ $23.4 \mu \mathrm{g} \mathrm{C}$ larva ${ }^{-1} \mathrm{~h}^{-1}$ ). Older (50 dph) larvae with $18.1 \mathrm{~mm}$ TL consumed both nauplii $(44 \pm 61.9$ prey larva $^{-1} \mathrm{~h}^{-1}$ ) and copepodites $\left(75 \pm 38.2\right.$ prey larva ${ }^{-1}$ $\mathrm{h}^{-1}$ ), which corresponded to $261 \pm$ $160.5 \mu \mathrm{g} \mathrm{C}$ larva ${ }^{-1} \mathrm{~h}^{-1}$. At the highest prey concentration, $35 \mathrm{dph}(14.7 \mathrm{~mm}$ TL) sardine larvae exclusively ingested copepodites at a rate of $81 \pm$ 18.0 prey larva ${ }^{-1} \mathrm{~h}^{-1}(249 \pm 55.3 \mu \mathrm{g} \mathrm{C}$ larva ${ }^{-1} \mathrm{~h}^{-1}$ ). Older (40 dph) larvae with $15.9 \mathrm{~mm}$ TL ingested both nauplii $\left(44 \pm 43.8\right.$ prey larva $\left.{ }^{-1} \mathrm{~h}^{-1}\right)$ and copepodites $\left(248 \pm 24.2\right.$ prey larva $\left.{ }^{-1} \mathrm{~h}^{-1}\right)$, which amounted to $792 \pm 103.9 \mu \mathrm{g} \mathrm{C}$ larva $^{-1} \mathrm{~h}^{-1}$. The results of the Chesson selectivity statistic confirmed the above-mentioned observations and showed that, in general, larvae $>20 \mathrm{dph}$ or $>10.1 \mathrm{~mm}$ TL tended to positively select copepodites, whereas younger larvae positively selected

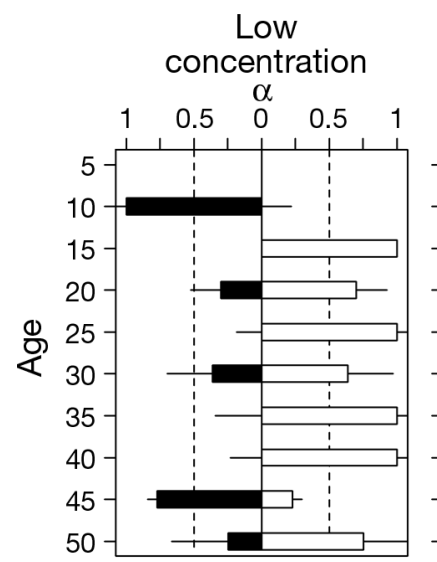

nauplii (Fig. 5). This pattern was very clear at the high food concentration diet, whereas at lower food availability there was much more scatter in the data.

\section{Gut contents}

The analysis of the gut contents of 252 larvae (size range from 3.9 to $23.9 \mathrm{~mm} \mathrm{TL}$ ) revealed that overall the percentage of larvae analysed with food in the guts was very low $(15.5 \%)$, although higher values were occasionally found (Table 3). The smallest sardine larvae with prey in the gut were $5.9 \mathrm{~mm}$ and $5 \mathrm{dph}$. Sardine larvae $<10 \mathrm{~mm}(<20 \mathrm{dph})$ only ingested nauplii, while older larvae $(>10 \mathrm{~mm}$ and $>20 \mathrm{dph}$ ) also had copepodites in the guts. The number of prey items per larva increased with prey concentration (Fig. 6). Maximum prey number per larvae at the low, medium and high prey concentrations were 5 prey at $45 \mathrm{dph}$ ( 3 nauplii and 2 copepodites; $18.37 \mathrm{~mm}$ TL larva), 7 prey at $50 \mathrm{dph}$ ( 7 copepodites; $18.5 \mathrm{~mm} \mathrm{TL}$ ) and 10 prey at $20 \mathrm{dph}$ (8 nauplii and 2 copepodites; $10.5 \mathrm{~mm}$ larval size), respectively.

Prey size significantly increased with increasing larval TL ( $\left.\mathrm{p}<0.001, \mathrm{r}^{2}=0.44, \mathrm{n}=113\right)$. In early sardine larvae ( 5.8 to $10 \mathrm{~mm}$ TL and $<20 \mathrm{dph}$ ) prey items ranged in total and prosome length (for nauplii and copepodites, respectively) from 91.8 to $243.7 \mu \mathrm{m}$. For larvae between 10 and $16 \mathrm{~mm}$ TL ( 20 to $40 \mathrm{dph}$ ), the Intermediate
concentration

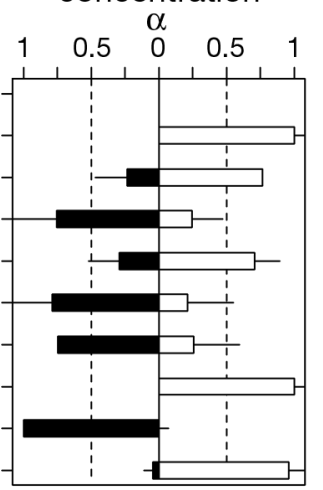

High concentration

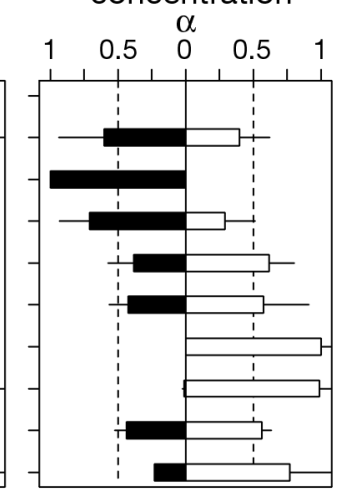

Fig. 5. Chesson $\alpha$ selectivity for nauplii (black bars) and copepodites (white bars) with larval age for 3 concentrations of nauplii and copepodites of Acartia grani. Diet concentrations are described in Table 2. $95 \%$ confidence intervals are shown 
Table 3. Presence (as \% of incidence) of Acartia grani (nauplii and copepodites) in the guts of sardine larvae from 5 to $50 \mathrm{dph}$ and for the 3 different diets

\begin{tabular}{|c|c|c|c|c|c|c|c|c|}
\hline \multirow[t]{3}{*}{ Age } & \multirow{2}{*}{\multicolumn{2}{|c|}{$\begin{array}{c}0.5 \text { nauplii } \mathrm{ml}^{-1}+ \\
0.1 \text { copepodites } \mathrm{ml}^{-1}\end{array}$}} & \multirow{2}{*}{\multicolumn{2}{|c|}{$\begin{array}{c}\text { Diets } \\
2 \text { nauplii } \mathrm{ml}^{-1}+ \\
0.5 \text { copepodites } \mathrm{ml}^{-1}\end{array}$}} & \multirow{2}{*}{\multicolumn{2}{|c|}{$\begin{array}{l}6 \text { nauplii ml } \mathrm{m}^{-1}+ \\
1 \text { copepodites } \mathrm{ml}^{-1}\end{array}$}} & \multirow{2}{*}{\multicolumn{2}{|c|}{ — Total }} \\
\hline & & & & & & & & \\
\hline & $\mathrm{n}$ & $\begin{array}{c}\text { Incidence } \\
(\%)\end{array}$ & $\mathrm{n}$ & $\begin{array}{l}\text { Incidence } \\
(\%)\end{array}$ & $\mathrm{n}$ & $\begin{array}{c}\text { Incidence } \\
(\%)\end{array}$ & $\mathrm{n}$ & $\begin{array}{c}\text { Incidence } \\
(\%)\end{array}$ \\
\hline 5 & 16 & 0.00 & 13 & 0.00 & 17 & 11.76 & 252 & 15.48 \\
\hline 10 & 12 & 25.00 & 8 & 0.00 & 14 & 0.00 & & \\
\hline 15 & 19 & 31.58 & 20 & 20.00 & 18 & 16.67 & & \\
\hline 20 & 13 & 46.15 & 12 & 16.67 & 12 & 33.33 & & \\
\hline 25 & 8 & 12.50 & 9 & 22.22 & 9 & 33.33 & & \\
\hline 30 & 5 & 0.00 & 6 & 0.00 & 4 & 0.00 & & \\
\hline 35 & 3 & 0.00 & 3 & 0.00 & 4 & 0.00 & & \\
\hline 40 & 2 & 0.00 & 2 & 0.00 & 2 & 0.00 & & \\
\hline 45 & 4 & 25.00 & 4 & 0.00 & 3 & 0.00 & & \\
\hline 50 & 3 & 0.00 & 3 & 33.33 & 4 & 25.00 & & \\
\hline
\end{tabular}

geny using the calanoid copepod Acartia grani as prey. It constitutes one of the few attempts to determine the ingestion rates of small pelagic fish larvae in relation to prey concentration (review in Peck et al. 2013).

\section{Feeding rates and prey selectivity}

Although confinement in small tanks can have an impact on the growth and feeding rates determined under laboratory conditions, the fact that the growth rates were similar to those deter-

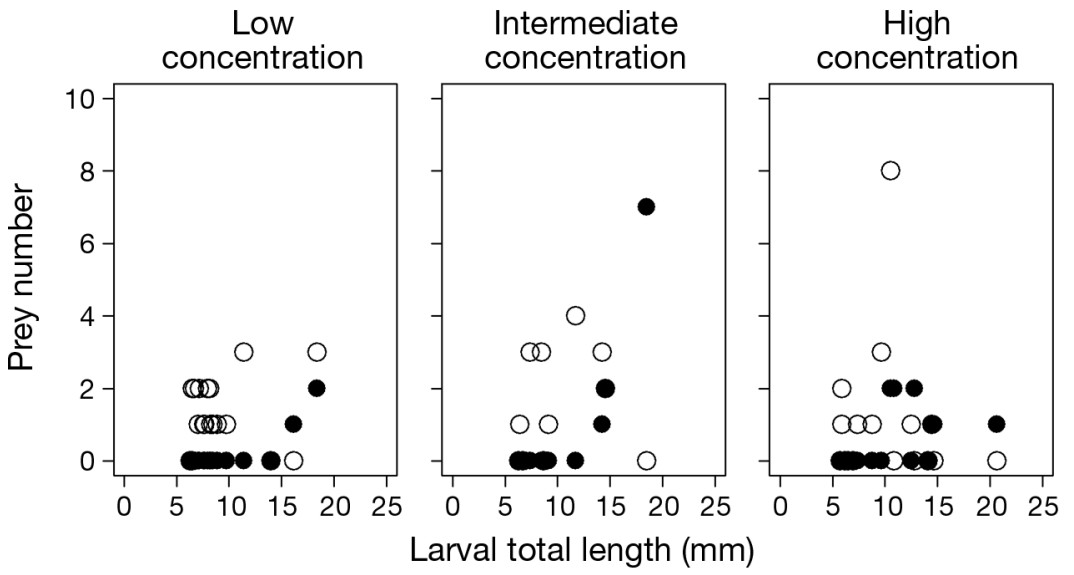

Fig. 6. Relationship between number of prey items in sardine larvae guts and larval size for 3 concentrations of nauplii (O) and copepodites (O) of Acartia grani. Diet concentrations are described in Table 2

mined in the wild off the Portuguese coast (e.g. Ré 1983, Chícharo et al. 2012) and that the Fulton's condition of sardine larvae reared with the same diet were shown to be similar to that of fast-growing sardine larvae in the wild (Moyano et al. 2014), suggests that the rates determined under the conditions used in our experiments are reliable.

Several field studies have indicated that calanoid copepods are key prey that are preferentially selected by the larvae of European sardine (e.g. Voss et al. 2009, Morote et al. 2010, Borme et al. 2013). Laboratory results have also demonstrated that European anchovy larvae had higher growth rates when fed the nauplii of the

prey found in guts ranged from 76.9 to $352.4 \mu \mathrm{m}$. Sardine larvae $>16 \mathrm{~mm}$ (>40 dph) did not ingest small prey and prey size was between 167.6 and $530.1 \mu \mathrm{m}$ between 45 and $50 \mathrm{dph}$, respectively (Fig. 7). No effect of prey concentration on the size of prey in the guts was observed (Fig. 7). The ratio between prey size and larvae size varied between 0.6 and 3.2 and was higher for small larvae $(<8 \mathrm{~mm}$ or $<20 \mathrm{dph}$ ) than for older larvae. This was not due to the prey size spectrum offered since larvae had larger copepodites than those found in the gut contents (Fig. 7).

\section{DISCUSSION}

In this study, we have described for the first time the ingestion rates of sardine larvae through onto- calanoid copepod A. grani compared with the harpacticoid Euterpina acutifrons (Garrido et al. 2012). Recent work on laboratory rearing of European sardine (S. Garrido pers. obs.) and European anchovy (Garrido et al. 2012) suggest that growth rates in the laboratory and field agree well when larvae are fed mixtures of different prey types (dinoflagellate, small zooplankton and the copepod A. grani) offered at $>2$ prey $\mathrm{ml}^{-1}$. These previous laboratory studies and the present study help reveal additional aspects of prey requirements that cannot be ascertained solely from field studies.

Early sardine larvae (5 and $10 \mathrm{dph}$, corresponding to 5.3 and $6.9 \mathrm{~mm}$ TL, respectively) showed inability to capture copepod nauplii, which is probably related to the poor swimming abilities of young larvae (Hunter 1981). A study of swimming behaviour of 


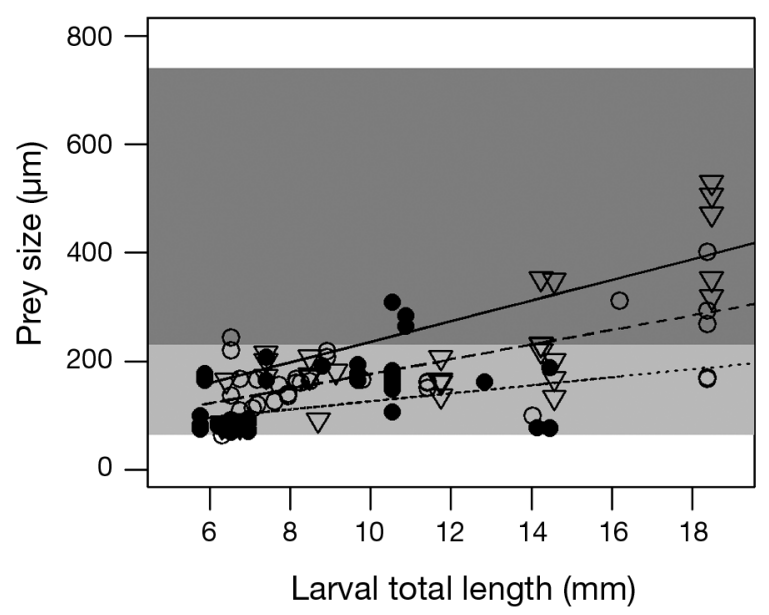

Fig. 7. Relationship between prey size $(\mu \mathrm{m})$ and larval size $(\mathrm{mm})$ for 3 concentrations of nauplii and copepodites of Acartia grani: low (open circles), intermediate (triangles) and high (filled circles) concentration. Diet concentrations are described in Table 2. Regressions of prey size (PS) versus larval total length (TL): maximum $\left(\mathrm{PS}_{\max }=46.4+0.019 \mathrm{TL}\right.$; solid line), mean ( $\mathrm{PS}_{\text {mean }}=42+0.014 \mathrm{TL}$; dashed line) and minimum $\left(\mathrm{PS}_{\min }=52.7+0.007 \mathrm{TL}\right.$ i dotted line $)$. Grey shading represents the prey size spectrum offered; light grey: A. grani nauplii, dark grey: A. grani copepodites

sardine larvae reported that early larvae were not capable of sustained swimming until $20 \mathrm{dph}$ and $>10.1 \mathrm{~mm}$ TL (Silva et al. 2014). In the present work, early sardine larvae were either not able to ingest copepod nauplii or had very low ingestion rates of those prey. This lower feeding threshold was age dependent, as older larvae were able to ingest copepod nauplii at the lowest concentration used, despite having very low ingestion rates. Further experiments should be done to test whether indeed sardine larvae have a lower feeding threshold, which should also include less-motile prey, which might be particularly important for younger larvae as being easier to capture. These results are in agreement with the finding of Morote et al. (2010) that these young larvae were unable to efficiently capture copepod nauplii. In our stocking tanks, early sardine larvae had to be fed rotifers and dinoflagellates to help guarantee early survival. At the beginning of the exogenous feeding period, sardine larvae require smaller prey with lower escape capability than copepod nauplii to enhance growth and survival, which has been also described for anchovy larvae (Garrido et al. 2012). The contribution of soft-bodied prey items and phytoplankton to the vital rates of fish larvae has been probably underestimated due to rapid digestion and/or deficient preservation using traditional methods of field collection and storage (Peck et al. 2013).
In the wild, ciliates can be an alternative to copepod nauplii as prey for first-feeding fish larvae (Fukami et al. 1999, Nagano et al. 2000, Friedenberg et al. 2012) and their importance to sardine early larvae should be addressed in future experiments.

Sardine larvae exhibit large ontogenetic changes in swimming behaviour characterized by longer pause durations in young larvae (about $33 \%$ of the time at $15 \mathrm{dph}$ ) and only search for prey during pause events (Silva et al. 2014). Several studies have demonstrated that low levels of food result in reduced growth, prolonged larval development and consequently an increased risk of mortality (Theilacker 1987, Pryor \& Epifano 1993). In the present study, ingestion rates and gut contents increased with increasing prey concentration. Younger larvae $(<15 \mathrm{dph} ; 7.7$ $\pm 1.35 \mathrm{~mm}$ TL) had very low consumption of nauplii at the lowest food concentration, and only at prey concentrations $\geq 2$ nauplii $\mathrm{ml}^{-1}$ were ingestion rates meaningful and fell in the range 38 to 113 nauplii lar$v^{-1} \mathrm{~h}^{-1}$. Sardine larvae were only able to ingest prey offered at low concentration from $40 \mathrm{dph}$ (15.9 $\mathrm{mm} \mathrm{TL}$ ) onwards, but only at rates that were $<10 \%$ of those of similar sized larvae offered the same prey at high concentration. From $15 \mathrm{dph}$ (8.5 mm TL), larvae were able to pursue and capture copepod nauplii more efficiently. Larvae older than $15 \mathrm{dph}$ (>8.5 mm TL) were capable of ingesting nauplii (at intermediate and high prey concentrations) and could capture copepodites at $>20 \mathrm{dph}(>10.1 \mathrm{~mm} \mathrm{TL})$ and adult copepods at $>30 \mathrm{dph}(>13.3 \mathrm{~mm} \mathrm{TL})$.

Larger larvae are able to swim faster and longer and therefore increase the encounter rate with prey. Fish larvae develop a mechanical support of the caudal fin, which makes older larvae stronger swimmers and, consequently, enhances their prey-searching ability and also increases prey capture success (Hunter 1981, Sabates \& Saiz 2000). Sardine larvae $>20$ dph (>10.1 mm TL) spend $100 \%$ of their time swimming and have a significantly higher number of prey attacks than smaller larvae (Silva et al. 2014). The increase in the swimming abilities of sardine larvae matches the timing of the notochord flexion at $20 \mathrm{dph}$ (Silva et al. 2014), coinciding with the beginning of the caudal fin formation and development of the swim bladder (Santos et al. 2007). These ontogenic changes result in gradually improved swimming performance as larvae develop, and are determinant for the vertical migration behaviour (Somarakis \& Nikolioudakis 2010). Moreover, when larvae are more active, they will have a higher probability of encountering prey because the probability of contact will increase (Munk \& Kiørboe 1985). 
Throughout ontogeny, mouth size, prey searching ability and capture success of fish larvae increase (Shirota 1970, Hunter 1981, Sabatés \& Saiz 2000) leading to concomitant changes in the amounts and sizes of ingested prey items. European sardine larvae demonstrated a gradual switch in ingested prey sizes and a marked increase in the ability to capture nauplii and copepodites from $20 \mathrm{dph}$ (>10 mm TL). At $50 \mathrm{dph}$ (18.1 mm TL), when prey were offered at 6 nauplii $\mathrm{ml}^{-1}$ and 1 copepodite $\mathrm{ml}^{-1}$, maximum ingestion rates were $863 \pm 39.6$ nauplii larvae ${ }^{-1} \mathrm{~h}^{-1}$ and $285 \pm 8.3$ copepodites larvae ${ }^{-1} \mathrm{~h}^{-1}$. Nauplii were most often found in the gut contents of larvae between 10 and $15 \mathrm{~mm}$ TL (from 20 to $35 \mathrm{dph}$ ), while larger larvae ( $>16 \mathrm{~mm}$ TL or $>40 \mathrm{dph}$ ) continued to feed on nauplii but preferred copepodites. Although an abrupt dietary shift from nauplii to copepodites has been postulated by Fernandez \& Gonzalez-Quiros (2006), our observations are in agreement with those of Conway et al. (1994), who found that the increase in the consumption of copepodites was gradual, and also with the results obtained in the northwest Mediterranean suggesting an increase in prey size as larval size increases (Morote et al. 2010). Morote et al. (2010) reported that the diet of sardine larvae from 10 to $15.8 \mathrm{~mm}$ (from 20 to $40 \mathrm{dph}$ ) was based on copepod nauplii and Clausocalanus post-nauplii, with size ranges similar to those eaten by sardine larvae in the ingestion experiments.

Prey size determined in gut contents of Sardina pilchardus increased with larval age and size in a similar manner as ontogenetic changes in prey sizes of northern anchovy Engraulis mordax larvae reared at the same temperature (Theilacker 1987). The range in prey sizes is similar for both species; prey were 91.8 to $243.7 \mu \mathrm{m}$ long in sardine larvae measuring $<9.5 \mathrm{~mm}$ standard length (SL) $(<20 \mathrm{dph})$ and 167.6 to $530.1 \mu \mathrm{m}$ in larvae $>15.1 \mathrm{~mm}$ SL $(<40 \mathrm{dph})$, where the conversion for SL is approximately $95 \%$ of TL (data not shown), while early northern anchovy larvae (from 4 to $6 \mathrm{~mm} \mathrm{SL}$ ) preferred 75 to $147 \mu \mathrm{m}$ prey (nauplii), and older larvae (6 to $9 \mathrm{~mm} \mathrm{SL}$ ) captured larger, 184 to $221 \mu \mathrm{m}$ (copepodite) prey. Field studies suggest a broader trophic flexibility in younger larvae, with increasing trophic specialization and more selective diets at larger body sizes (older ages). This trophic specialization includes a greater dominance of large prey size with increasing age and/or size (Laiz-Carrión et al. 2011). The ratio between prey size and sardine larvae size decreased throughout ontogeny, despite the fact that larvae had larger copepodites available (but not found in the gut contents). Larvae probably optimize their energy intake by capturing smaller and less mobile copepodites and nauplii thereby decreasing the handling time and maximizing capture success of prey.

The ingestion rates of the larvae of various clupeid species have been estimated in a handful of previous studies. The ingestion rates of sardine larvae in the present study $\left(15^{\circ} \mathrm{C}\right)$ are higher than estimates $(0.14$ to 1.26 Artemia nauplii larva ${ }^{-1} \mathrm{~d}^{-1}$ ) obtained for 12 to $18 \mathrm{~mm}$ SL Atlantic herring Clupea harengus larvae fed at 0.1 prey $\mathrm{ml}^{-1}$ at 7 to $9^{\circ} \mathrm{C}$ (Checkley 1984). In contrast, 20 to $35 \mathrm{dph}$ (10.2 to $14.6 \mathrm{~mm}$ TL) sardine larvae had ingestion rates of $5 \pm 4.0$ nauplii larvae l $^{-1}$ $\mathrm{h}^{-1}$ and $3 \pm 2.7$ copepodites larvae ${ }^{-1} \mathrm{~h}^{-1}$ at 0.5 and 0.1 prey $\mathrm{ml}^{-1}$, respectively. At slightly warmer temperatures $\left(10\right.$ to $\left.11^{\circ} \mathrm{C}\right)$ at initial prey concentrations of 0.01 to $0.05 \mu \mathrm{g} \mathrm{C} \mathrm{ml}^{-1}$, ingestion rates of 11 to $13 \mathrm{~mm}$ (19 to $22 \mathrm{dph}$ ) Pacific herring Clupea pallasi larvae ranged from 0.30 to $0.50 \mu \mathrm{g} C$ larvae $^{-1} \mathrm{~h}^{-1}$ (Friedenberg et al. 2012), which is significantly lower than found here for European sardines $(1.92 \pm 1.31 \mu \mathrm{g} \mathrm{C}$ larva $^{-1} \mathrm{~h}^{-1}$ ). These differences can be due to differences between species and/or temperatures since the latter affects rates of metabolism and prey ingestion rates. The mean clearance rates for sardine larvae on nauplii $\left(8.9 \mathrm{ml} \mathrm{larva}^{-1} \mathrm{~h}^{-1}\right)$ are similar to that determined for Pacific herring larvae ( 7 to $15 \mathrm{ml}$ larva $^{-1} \mathrm{~h}^{-1}$ ), for the same size ranges as above. The clearance rate illustrates the direct impact of larvae on their prey in relation to prey availability and is an appropriate measure to use in clupeid larvae that have adopted a cruise foraging strategy (Munk \& Kiørboe 1985). Thus, larvae at cold temperatures have a lower percentage of time spent swimming (and possibly lower swimming speed), which leads to decreased searched volumes per unit time. Northern anchovy larvae reared at $15.5^{\circ} \mathrm{C}$ and offered 2 and 25 rotifers $\mathrm{ml}^{-1}$ had maximum ingestion rates of 0.35 and $0.81 \mu \mathrm{g} \mathrm{C}$ larva ${ }^{-1} \mathrm{~h}^{-1}$, respectively, at $14 \mathrm{dph}$ (Theilacker 1987). At the same temperature, $15 \mathrm{dph}$ European sardine larvae had almost 10 -fold higher ingestion rates $\left(4.5\right.$ and $7.0 \mu \mathrm{g} \mathrm{C}$ larvae $\mathrm{e}^{-1} \mathrm{~h}^{-1}$ at 2 and 6 nauplii $\mathrm{ml}^{-1}$, respectively). However, the numerical ingestion rate of northern anchovy (2.9 to 6.7 rotifers larva $^{-1} \mathrm{~h}^{-1}$ ) is higher than that of European sardine larvae $\left(0.3\right.$ to 0.5 copepods larva $\left.{ }^{-1} \mathrm{~h}^{-1}\right)$ and differences in carbon-specific ingestion rate are due to differences in the average carbon content of the prey. On the other hand, ingestion rates of the bay anchovy Anchoa mitchilli larvae at $26^{\circ} \mathrm{C}$ were 15 to $16 \mu \mathrm{g}$ larva ${ }^{-1} \mathrm{~h}^{-1}$ (Houde \& Schekter 1980), which is higher than the ingestion rates determined here for sardines at similar age and initial prey concentrations $\left(\leq 0.1\right.$ prey $\left.\mathrm{ml}^{-1}\right)$. 


\section{Vital rates and metabolic balance}

The carbon content ingested by sardine larvae in our study can be compared to estimates of amounts of ingested food energy required to support larval growth rates in situ and/or standard respiration rates estimated by Moyano et al. (2014) in the laboratory. This comparison suggests that larvae are unable to forage at sufficiently high rates at low prey concentrations to support growth rates observed in nature, particularly for early development stages $(<40 \mathrm{dph}$ or $<15.9 \mathrm{~mm}$ TL) and foraging at low prey concentrations is insufficient to sustain growth and metabolic costs for all the ages tested (Fig. 3). On the contrary, the intermediate concentration was often, and the high prey concentration was always, sufficient to support metabolic costs as well as mean growth rate costs of sardine larvae in the wild (Fig. 4). Note, for these estimates, we assumed that C was $40 \% \mathrm{DW}$, gross-growth efficiency was $40 \%$ and, since larvae are visual feeders (Blaxter 1969, Morote et al. 2010, Borme et al. 2013), larvae fed only during a $16 \mathrm{~h}$ photoperiod each day.

Similarly high prey requirements ( $>1$ nauplii $\mathrm{ml}^{-1}$ ) to ensure survival have been estimated for northern anchovy larvae (Hunter 1977, Theilacker 1987). The results of these studies on various anchovy and sardine species suggest that these small pelagic species must find and remain in plankton patches to survive, at least during the early stages when their swimming abilities and prey capture success are relatively poor. On the contrary, for other clupeid species such as Atlantic herring, patches of dense plankton concentrations are apparently not necessary for growth and survival in the sea (Kiørboe \& Munk 1986). The difference in prey requirements determined in laboratory and field studies may arise from the inability of net catches to sufficiently characterize in situ prey concentrations actually experienced by early feeding larvae in the wild that forage within patchy prey environments (MacKenzie \& Kiørboe 1995, Peck et al. 2013). There is strong evidence from field studies of the importance of high prey concentrations in habitats, as shown for the Pacific sardine Sardinops sagax, which preferentially spawns in habitats and during periods of enhanced food availability (Aceves-Medina et al. 2009), which has been interpreted to be a reproductive strategy to enhance the probability of larval survival (Riveiro et al. 2000).

Acknowledgements. This work was supported by Fundação para a Ciência e Tecnologia (FCT) as part of the project VITAL (Vital rates of pelagic fish larvae PTDC/MAR/ 111304/2009). Project MODELA (PTDC/MAR/098643/2008) partially supported this work. S.G. is supported by FCT through a Post-Doctoral Fellowship (SFRH/BPD/ 38332/ 2007). The microalgae Rhodomonas baltica was provided by the Assemble Program (grant 227799) funded under the European Community - Research Infrastructure Action under the FP7 'Capacities'. E.S. was funded by project TOPCOP (CTM2011-23480). Thanks are due to A. Teodósio (CCMAR_Univ. Algarve) and all the team of the Oceanário de Lisboa for their collaboration, particularly N. Baylina and H. Batista.

\section{LITERATURE CITED}

Aceves-Medina G, Palomares-García R, Gómez-Gutiérrez J, Robinson CJ, Saldierna-Martínez RJ (2009) Multivariate characterization of spawning and larval environments of small pelagic fishes in the Gulf of California. J Plankton Res 31:1283-1297

Anderson JT (1988) A review of size dependent survival during pre-recruit stages of fishes in relation to recruitment. J Northw Atl Fish Sci 8:55-66

Bakun A (1996) Patterns in the ocean: ocean processes and marine population dynamics. University of California, San Diego, CA and Centro de Investigaciones Biológicas de Noroeste, La Paz

Blaxter JHS (1963) The feeding of herring larvae and their ecology in relation to feeding. Calif Coop Ocean Fish Invest 10:79-88

Blaxter JHS (1969) Experimental rearing of pilchard larvae, Sardina pilchardus. J Mar Biol Assoc UK 49:557-575

Borme D, Tirelli V, Palomera I (2013) Feeding habits of European pilchard late larvae in a nursery area in the Adriatic Sea. J Sea Res 78:8-17

Catalán I, Folkvord A, Palomera I, Quílez-Badía G, Kallianoti F, Tselepides A, Kallianotis A (2010) Growth and feeding patterns of European anchovy (Engraulis encrasicolus) early life stages in the Aegean sea (NE, Mediterranean). Estuar Coast Shelf Sci 86:299-312

Checkley DM Jr (1982) Selective feeding by Atlantic herring (Clupea harengus) larvae on zooplankton in natural assemblages. Mar Ecol Prog Ser 9:245-253

Checkley DM Jr (1984) Relation of growth to ingestion for larvae of Atlantic herring Clupea harengus and other fish. Mar Ecol Prog Ser 18:215-224

Chesson J (1983) The estimation and analysis of preference and its relationship to foraging models. Ecology 64: 1297-1304

Chícharo MA, Amaral A, Faria A, Morais P and others (2012) Are tidal lagoons ecologically relevant to larval recruitment of small pelagic fish? An approach using nutritional condition and growth rate. Estuar Coast Shelf Sci 112: 265-279

Conway DVP, Coombs SH, Fernandez de Puelles ML, Tranter PRG (1994) Feeding of larval sardine, Sardina pilchardus (Walbaum), off the north coast of Spain. Bol Inst Esp Oceanogr 10:165-175

Fernandez IM, Gonzalez-Quiros R (2006) Analysis of feeding of Sardina pilchardus (Walbaum, 1792) larval stages in the central Cantabrian Sea. Sci Mar 70S1:131-139

Friedenberg LE, Bollens SM, Rollwagen-Bollens G (2012) Feeding dynamics of larval Pacific herring (Clupea pallasi) on natural prey assemblages: the importance of protists. Fish Oceanogr 21:95-108

Fukami K, Watanabe A, Fujita S, Yamaoka K, Nishijima T (1999) Predation on naked protozoan microzooplankton 
by fish larvae. Mar Ecol Prog Ser 185:285-291

Garrido S, Santos AMP, Santos A, Ré P (2009) Spatial distribution and vertical migrations of fish larvae communities off Northwestern Iberia sampled with LHPR and Bongo nets. Estuar Coast Shelf Sci 84:463-475

Garrido S, Saiz E, Peters J, Ré P and others (2012) Effect of food type and concentration on growth and fatty acid composition of early larvae of the anchovy (Engraulis encrasicolus) reared under laboratory conditions. J Exp Mar Biol Ecol 434-435:16-24

Hjort J (1914) Fluctuations in the great fisheries of Northern Europe viewed in the light of biological research. Rapp p-v Réun Cons Int Exp Mer 20:1-228

Houde ED, Schekter RC (1980) Feeding by marine fish larvae: developmental and functional responses. Environ Biol Fishes 5:315-334

Hunter JR (1976) Culture and growth of northern anchovy, Engraulis mordax, larvae. Fish Bull 74:81-88

Hunter JR (1977) Behavior and survival of northern anchovy, Engraulis mordax, larvae. Calif Coop Oceanic Fish Invest Rep 19:138-146

Hunter JR (1981) Feeding ecology and predation of marine fish larvae. In: Lasker R (ed) Marine fish larvae: morphology, ecology and relation to fisheries. Washington Sea Grant Program, Univ. Wash. Press, Seattle, WA, p 33-77

Hunter JR, Thomas GL (1974) Effect of prey distribution and density on the searching and feeding behavior of larval anchovy Engraulis mordax Girard. In: Blaxter JHS (ed) The early life history of fish. Springer-Verlag, Berlin, p 559-574

ICES (International Council for the Exploration of the Sea) (2013) Report of the Working Group on Southern Horse Mackerel, Anchovy and Sardine (WGHANSA). CM 2013/ACOM, 16, ICES, Copenhagen, p 752

Kiørboe T, Munk P (1986) Feeding and growth of larval herring, Clupea harengus, in relation to density of copepod nauplii. Environ Biol Fishes 17:133-139

Laiz-Carrión R, Quintanilla JM, Mercado JM, García A (2011) Combined study of daily growth variability and nitrogen-carbon isotopic signature analysis of schooling Sardina pilchardus larvae. J Fish Biol 79:896-914

Lasker R (1975) Field criteria for the survival of anchovy larvae: the relation between inshore chlorophyll maximum layers and succesfull first feeding. Fish Bull 73:847-855

Lasker R, Feder HM, Theilacker GH, May RC (1970) Feeding, growth and survival of Engraulis mordax: larvae reared in the laboratory. Mar Biol 5:345-353

> MacKenzie BR, Kiørboe T (1995) Encounter rates and swimming behavior of pause-travel and cruise larval fish predators in calm and turbulent laboratory environments. Limnol Oceanogr 40:1278-1289

Morote E, Olivar MP, Villate F, Uriarte I (2010) A comparison of anchovy (Engraulis encrasicolus) and sardine (Sardina pilchardus) larvae feeding in the Northwest Mediterranean: influence of prey availability and ontogeny. ICES J Mar Sci 67:897-908

Moyano M, Garrido S, Teodósio MA, Peck MA (2014) Standard metabolism and growth dynamics of laboratoryreared larvae of Sardina pilchardus. J Fish Biol 84:

Editorial responsibility: Stylianos Somarakis,

Heraklion, Greece
1247-1255

- Munk P (1997) Prey size spectra and prey availability of larval and small juvenile cod. J Fish Biol 51:340-351

Munk P, Kiørboe T (1985) Feeding behaviour and swimming activity of larval herring (Clupea harengus) in relation to density of copepod nauplii. Mar Ecol Prog Ser 24:15-21

Nagano N, Iwatsuki Y, Kamiyama T, Shimzu H, Nakata H (2000) Ciliated protozoans as food for first-feeding larval grouper, Epinephelus septemfasciatus: laboratory experiment. Plankton Biol Ecol 47:93-99

Peck MA, Hufnagl M (2012) Can IBMs explain why most larvae die in the sea? Model scenarios and sensitivity analyses reveal research needs. J Mar Syst 93:77-93

Peck MA, Reglero P, Takahashi M, Catalán IA (2013) Life cycle ecophysiology of small pelagic fish and climatedriven changes in populations. Prog Oceanogr 116: 220-245

> Pryor VK, Epifano CE (1993) Prey selection by larval weakfish (Cynoscion regalis): the effects of prey size, speed, and abundance. Mar Biol 116:31-37

Ré P (1983) Growth of pilchard larvae, Sardina pilchardus (Walbaum, 1792) in relation to some environmental factors. Invest Pesq 47:277-283

Riveiro I, Guisande C, Lloves M, Maneiro I, Cabanas JM (2000) Importance of parental effects on larval survival in Sardina pilchardus. Mar Ecol Prog Ser 205:249-258

Sabatés A, Saiz E (2000) Intra- and interspecific variability in prey size and niche breadth of myctophiform fish larvae. Mar Ecol Prog Ser 201:261-271

Santos AMP, Chícharo A, Dos Santos A, Moita T, Oliveira PB, Peliz A, Ré P (2007) Physical-biological interactions in the life history of small pelagic fish in the Western Iberia upwelling ecosystem. Prog Oceanogr 74:192-209

Shirota A (1970) Studies on the mouth size of fish larvae. Bull Jpn Soc Fish Oceanogr 36:353-368 (in Japanese)

Silva L, Faria AM, Chícharo MA, Garrido S (2014) Ontogeny of swimming behaviour in sardine Sardina pilchardus larvae and effect of larval nutritional condition on critical speed. Mar Ecol Prog Ser 504:287-300

Somarakis S, Nikolioudakis N (2010) What makes a late anchovy larva? The development of the caudal fin seen as a milestone in fish ontogeny. J Plankton Res 32:317-326

Stratoudakis Y, Coombs S, Lanzós AL, Halliday N and others (2007) Sardine (Sardina pilchardus) spawning seasonality in European waters of the northeast Atlantic. Mar Biol 152:201-212

Theilacker GH (1987) Feeding ecology and growth energetics of larval northern anchovy, Engraulis mordax. Fish Bull 85:213-228

> van der Lingen CD (2002) Diet of the sardine Sardinops sagax in the southern Benguela upwelling ecosystem. S Afr J Mar Sci 24:301-313

- Voss R, Dickmann M, Schmidt JO (2009) Feeding ecology of sprat (Sprattus sprattus 1.) and sardine (Sardina pilchardus w.) larvae in the German Bight, North Sea. Oceanologia 51:117-138

Whitehead PJP, Nelson GJ, Wongratana T (1988) Clupeoid fishes of the world. Engraulidae. Fisheries Synopsis 1257 (part 2), FAO, Rome, p 305-579

Submitted: May 5, 2014; Accepted: August 8, 2014

Proofs received from author(s): November 28, 2014 